\title{
Propagation of Radiofrequency Electromagnetic Fields in Geological Conductors
}

\author{
Volker Fritsch

\begin{abstract}
Contribution From the Experimental Station for Geo-electricity and Lightning Protection, Arsenal, Objekt 3, Vienna III, Austria
\end{abstract}

(Received March 12, 1962; revised September 28, 1962)

\begin{abstract}
Propagation of radiofrequency electromagnetic fields in conducting spaces has been the subject of extensive theoretical investigations. Still, the knowledge gained cannot always be applied directly to propagation in the upper strata of the earth. The reason for this is that these strata consist of geological conductors which are arranged in a complicated way. One can, of course, give specified values of conductivity and dielectric constant for geological conductors, and apply these to subsequent calculations. But most theoretical investigations apply either to homogeneous spaces or to spaces having an electrically simple structure. However, the electrical structure of the spaces occupied by geological conductors is almost always very complicated. If this fact is not taken into account sufficiently, one can never obtain agreement between experimental results and theoretical calculations. The author, who has been dealing with these problems for many years, is trying here to provide a survey of the inherent difficulties due to the complicated structure of geological conductors. Although the pertinent factors have been only very inadequately investigated up to now, it is hoped that further investigations can be stimulated by this discussion.
\end{abstract}

\section{Introduction}

\subsection{Statement of the Problem}

Propagation of a radiofrequency electromagnetic field along a path contained wholly, or in part, within a space occupied by geological conductors is the subject of this investigation. It is assumed that quasi-stationary propagation conditions always exist. This requirement is met approximately whenever the length of the path under investigation is small as compared to a quarter-wave length in the space under investigation.

In general, one will have to deal with wavelengths underground that are between about one-third and one-ifth as long as those measured in air. Therefore, the scope of investigation is restricted to shorter paths for shorter wavelengths. The problem would be completely solved if the strength and relative phase of the field could be calculated for every point of a completely described space.

\subsection{Prior Investigations}

The influence of the electrical properties of the top layer of the ground on field strength propagation has already been investigated in the early years of radio engineering [Sommerfeld, 1910; Zenneck, 1907 ; and others]. Some time later, propagation conditions underground were studied both theoretically and experimentally by Löwy [1920], and others. At that time, however, these investigators had to be satisfied with very modest apparatus. Nevertheless,

1 Translated from the German by Albrecht P. Barsis. The assistance of G. V. Keller of the Geophysics Branch, U. S. Geological Survey, is gratefully acknowledged. it was indicated that electromagnetic waves propagate not only above ground, but also within the ground strata [Zehnder, 1911].

During the period between the two world wars, and especially during World War II, investigations were intensified.

Based upon these older studies, the influence of the electrical properties of the ground on the propagation of waves was further investigated by Alpert, Migulin, and Ryasin [1941]; Grosskopf [1943]; Grosskopf and Vogt [1943]; Howell [1943]; Strutt [1932]; and especially by Wait [1953, 1954, 1957].

The propagation of waves underground was studied primarily by Eve, Keys, and Lee [1929, 1932]; McGehee [1954]; Haycock, Madsen, and Hurst [1949]; Horton [1946]; and especially by Petrovsky, et al. [1908]. In addition, very extensive experimental investigations in caves and mines were conducted by Cooper [1948]; Doborzyński [1936]; Felegy [1953]; Fritsch [1932]; Ilsley, Freeman, and Zellers [1928]; Joyce [1931]; Silverman and Sheffet [1942]; Stern [1931]; Wadley [1946]; and many others.

Smith-Rose [1933], Wait [1953], and others have made a close investigation of the very important influence of frequency under different geological assumptions. Furthermore, there have been investigations of the influence of frequency on the electrical properties of ice (Granier, among others [1924]). Also, Wundt [1940] and Wedensky [1937] treated the penetration of fields into rocks.

In conclusion, one may state today that in many respects the field has been well investigated theoretically and experimentally. In spite of this, much remains to be done, particularly with regard to experimental work. 


\subsection{Viewpoints Regarding Treatment of the Problem}

Wave propagation in homogeneous media of known conductivity and dielectric constant is adequately understood. However, in practice, difficulties are largely due to the following factors:

(a) Conductivity and dielectric constants of most geological conductors are complicated functions, especially of frequency.

(b) Natural rocks are mostly not geologically homogeneous, but have a complicated structure. The field is reflected and refracted by the planes of discontinuity.

(c) Since the fields are frequently propagated in natural rocks with different velocities along different paths, phase shifts of the superimposed fields appear.

To answer such questions, large-scale experiments are necessary. One can obtain useful mean values which can be applied to theoretical considerations only when large volumes of space are used.

A basic requirement for the evaluation of experimental studies is a knowledge of the geo-electrical properties and structure of the space between transmitter and receiver. For this purpose, one must perform geo-electric soundings from the surface, or from other accessible points of this space [Fritsch, 1961], giving special attention to the planes of discontinuity, faults, and similar phenomena.

As transmitters and receivers always have to be located at points which are accessible from the surface of the earth, there is at least a theoretical possibility of propagation via the air space between transmitter and receiver. In all measurements, this "bypass wave" either has to be suppressed, or must be taken into account.

\section{General Remarks on Propagation in a Conducting Space}

Petrowsky [1908]; Smith-Rose and Barfield [1926]; Ilsley, Freeman, and Zellers [1928]; Eve, Keys, and Lee [1929]; Petrowsky [1929]; Eve [1932]; Zuhrt [1933]; Brune [1937]; Fritsch [1939]; Silverman and Sheffet [1942]; Cooper [1948]; Haycock, Madsen, and Hurst [1949]; Bays [1952]; Pritchett [1952]; McGehee [1954]; and Doluchanov [1956].

\subsection{General Concepts and Notations}

In this paper, the following notation will be used:

Figure 1 shows the transmitter as the source of the field, designated by $S$, and the receiver as the sink where the field has to be measured, designated by $E$. Crudely speaking, waves propagate along the path, $S \ldots A \ldots B \ldots E$, from transmitter to receiver. Between points $A$ and $B$, it traverses a space occupied by geological conductors. The mean resistivity of this space is $\rho_{g}$ and its mean dielectric constant is $\epsilon_{g}$. The path sections $\overline{S A}$ and $\overline{B E}$ are assumed to be through the air. We want to designate the section $\overline{A B}$ of the entire path as a "cut."

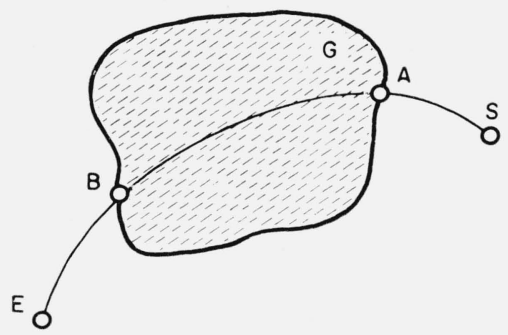

Figure 1. Wave propagation in a geological conductor.

Let the field be described by its electric and mag.. netic amplitude $\left(E_{0}\right.$ and $\left.H_{0}\right)$, by its relative phase $\phi_{0}$, and by its frequency, $f$. We then have $\omega=2 \pi f$, and wavelength, $\lambda=a f^{-1}$, where $a$ is the velocity of propagation.

As customary in geo-electric work, we measure the resistivity in ohmmeters $(\Omega m)$, and the reciprocal conductivity, $\sigma=\rho^{-1}$, in mhos per meter $\left(\Omega^{-1} m^{-1}\right.$ $\left.=S m^{-1}\right)$. Let the dielectric constant be given by

$$
\epsilon=\epsilon^{\prime} \frac{1}{36 \pi} 10^{-9}\left(\mathrm{Fm}^{-1}\right)
$$

with the relative dielectric constant, $\epsilon^{\prime}$. Analogous to this, let the permeability be given by

$$
\mu=\mu^{\prime} 4 \pi 10^{-7}\left(\mathrm{Hm}^{-1}\right)
$$

with the relative permeability, $\mu^{\prime}$.

\subsection{Attenuation, Reflection, and Range}

We assume the source at point $A$ and the sink at $B$. Let the conductivity of the space, $G$, be $\sigma_{\gamma}$, and its dielectric constant, $\epsilon_{\gamma}$, and the length of the path, $\overline{A B}$, be designated by $x$.

In accordance with the well-known laws of propagation theory, we generally obtain components of Maxwell's equations if we choose a Cartesian coordinate system whose $x$-axis coincides with the propagation direction.

For a dielectric medium,

$$
\epsilon \frac{\partial \bar{E}}{\partial t}=\operatorname{curl} \bar{H} ; \operatorname{div} \bar{E}=0 ;
$$

for a lossy medium

$$
\left(\epsilon-j \frac{\sigma}{\omega}\right) \frac{\partial \bar{E}}{\partial t}=\operatorname{curl} \bar{H}
$$

where $\left(\epsilon-j \frac{\sigma}{\omega}\right)$ is also designated as the complex die-

lectric constant. Developing these equations, we obtain for the field strength at $B$ : 
$E_{z}=E_{0} e^{-\delta x} \cos \omega\left(t-\frac{x}{a_{g}}\right)$

and

$\left.\begin{array}{rl}H_{y}=\frac{\sqrt{n^{2}+K^{2}}}{120 \pi} E_{0} e^{-\delta x} \cos [ & \omega\left(t-\frac{x}{a_{g}}\right) \\ & \left.-\arctan \frac{K}{n}\right]\end{array}\right\}$

if the field strength value, $E_{0}$, exists at point $A$. Equation (1) assumes plane wave conditions. In the above, $\delta$ is the very important attenuation constant

$$
\delta=\frac{2 \pi}{\lambda} K
$$

$a_{g}$ is the velocity of propagation of the field in the space occupied by geological conductors:

$$
a_{g}=\frac{a_{0}}{n},
$$

where $a_{0}$ is the velocity of propagation in a vacuum. The parameters $n$ and $K$ in general are given by:

$$
\left.\begin{array}{l}
n= \pm \sqrt{\frac{1}{2}\left[\epsilon_{g}^{\prime}+\sqrt{\left.\epsilon_{g}^{\prime 2}+\left(60 \lambda \sigma_{g}\right)^{2}\right]}\right.} \\
K= \pm \sqrt{\frac{1}{2}\left[-\epsilon_{g}^{\prime}+\sqrt{\epsilon_{g}^{\prime 2}+\left(60 \lambda \sigma_{g}\right)}\right]^{2}}
\end{array}\right\} .
$$

In an almost entirely dielectrically conducting space, where $\epsilon^{\prime} \gg 60 \lambda \sigma_{g}$, eq (4) reduces to:

$$
\left.\begin{array}{l}
n \simeq \sqrt{\epsilon_{g}^{\prime}} \\
K \simeq \frac{60 \lambda \sigma_{\sigma^{\prime}}}{2 \sqrt{\epsilon_{g}^{\prime}}}
\end{array}\right\} .
$$

We then have:

$$
\delta=\frac{60 \pi \sigma_{g}}{\sqrt{\epsilon_{g}^{\prime}}} \text { and } a_{g} \simeq \frac{a_{0}}{\sqrt{\epsilon_{g}^{\prime}}} .
$$

In a principally ohmic conducting space, one similarly obtains from eq (4), when $\epsilon_{g} \ll 60 \lambda \sigma_{g}$,

$$
\left.\begin{array}{l}
n \simeq \sqrt{30 \lambda \sigma_{g}} \\
K \cong \sqrt{30 \lambda \sigma_{g}}
\end{array}\right\}
$$

resulting in

$$
\delta=2 \pi \sqrt{\frac{30 \sigma_{g}}{\lambda}} \text { and } a_{g}=\frac{a_{0}}{\sqrt{30 \lambda_{g}}} .
$$

Equations (4a), as an example, refer to attenuation in a dry potash deposit, but those denoted by (4b) are applicable to naturally moist limestone. We chall see later that field-strength values calculated $n$ accordance with eqs (1) through (4) do not always agree with values obtained experimentally. This is not necessarily an argument against the applicability of the elementary propagation theory based on plane waves, but is due to additional effects, especially the complicated dependence of $\sigma_{g}$ and $\epsilon_{g}$ on frequency [Wait, 1959].

If a field is radiated toward a plane separating two media with differing electrical properties, it is usually split into three component fields. One component penetrates into the medium situated beyond the plane of discontinuity, a second component is reflected, and the third one may be guided along this plane.

Reflection and refraction at the surface of the earth and by conducting layers of the ionosphere have been widely investigated. However, in the interior of the earth, circumstances are substantially more complicated. First of all, the number of planes of discontinuity may be very large. The thickness of the strata between various planes of discontinuity is often relatively small, as we shall see later, and mostly comparable to a quarter-wave length. Therefore, it does not seem possible as yet to apply our knowledge of wave propagation-say, along the surface of the earth - to planes of discontinuity in the earth's uppermost strata. More likely, it will first be necessary to treat these problems experimentally.

One important parameter is the so-called "skin depth," which, in general, is a measure of the length of the particular path along which field strength is attenuated by a given amount. If the length of this path is designated by $S$, and the field strength at the end points by $E_{1}$ and $E_{2}$, then the so-called "skin depth," $S$, is that path for which $E_{1} / E_{2}=e$. This factor is of little practical use, being merely a comparative parameter. Range values under the surface of the earth which can be obtained in practice would correspond approximately to the condition $E_{1} / E_{2}=10^{6}$.

If one plots range values measured toward different directions from a given source and for a constant ratio $E_{1} / E_{2}$, a surface is generated as the locus of all resulting path endpoints. The intersection of this surface with a plane at an arbitrary orientation is the range diagram. Most of the time, this plane contains the equator of the transmitting antenna. If the source is contained in a space which is completely homogeneous geo-electrically, the range diagram is determined solely by the characteristics of the transmitting antenna. We designate this diagram as the "normal" one. However, if the space investigated is not homogeneous (almost always the case), we obtain as the "actual" diagram a curve which is deformed as compared to the "normal." Thus, it is our task to explain this deformation from the standpoint of geo-electricity.

\subsection{Phase Structure}

Electric and magnetic amplitude are interdependent, as is well known. We have

$$
H_{\mathrm{y} o}=\frac{\sqrt{n^{2}+K^{2}}}{120 \pi} E_{z o}
$$


for a plane wave. In the same way, the phase displacement between the electrical and the magnetic field is dependent on the geo-electrical properties of the space. For the same conditions, the phase angle $\phi$ is given by

$$
\phi=\arctan \frac{K}{n} \text {. }
$$

In order to represent the phase structure of the field in the interior of a space occupied by geological conductors, one connects points of equal phase, $\left(\phi / \phi_{0}=\right.$ constant), by lines which are designated equiphase contours.

\section{The Geological Conductor}

Granier [1924]; Ratcliffe and White [1930]; SmithRose [1933]; McPetrie [1934]; Bimalendu and Khastgir [1936]; Smith-Rose [1936]; Banerjee and Joshi [1938]; Khastgir and Charkravarty [1938]; McKinnon [1940]; Grosskopf and Vogt [1943]; Löb [1943]; Müller [1943]; Eliassen [1957].

\subsection{Structure}

In present-day radio engineering electromagnetic fields are calculated, in a simple manner, for homogeneous or stratified media. Consequently the fields show a quite simple structure. In nature, however, conditions are much more complicated. This will be demonstrated by means of a few examples:

Figure 2a shows a specific example of the structure of the earth's uppermost strata. Sediments (2), mostly of high resistivity, are situated above ground water level (GS), but below the erosion layer (1), which usually has a very small resistivity and seldom attains relatively large thickness. The ground water level in most cases, but not always, separates two layers which are quite different electrically. The rock strata below the water table (3) are usually highly conductive.

The conductivity of the impermeable rock strata (4), if igneous bedrock is considered, is very small. As shown by figure $2 \mathrm{~b}$, the impermeable layer can also consist of very fine-grained sediments, of loam, clay, marl, etc. In such cases it has resistivity values mostly lower than those of the strata below the water table. Then, too, the solid bedrock strata (5) are frequently located very deep below the surface.

The thickness of layer (1) is usually very small. Layers (2) and (3), however, can be up to several hundred meters thick; in deep sedimentary basins values up to even 5 to 10 kilometers may exist. The same holds for layer (4) in the structure shown in figure $2 \mathrm{~b}$.

The resistivity values in figure 2 naturally vary frequently within quite large limits. Values given correspond with the assumption that the ground water is fresh water. Assumptions have to be much more complicated for saline ground water (much more common in the United States) or when sea water penetrates underground in coastal regions.

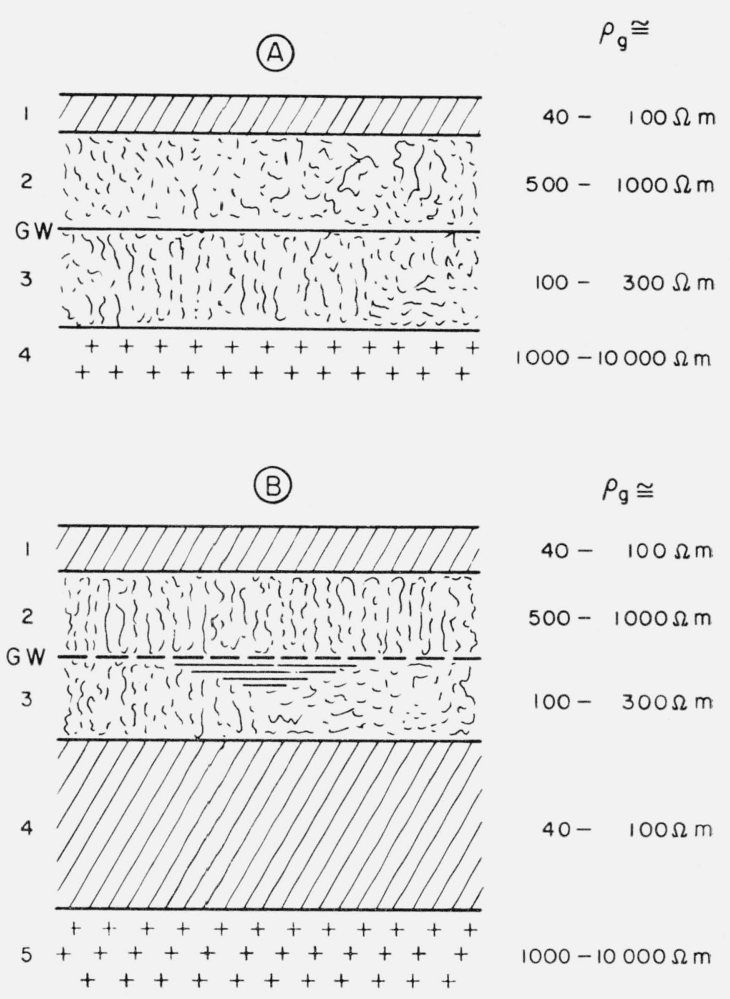

Figure 2. Structure of the top ground layers.

Figure 3 presents the formation of well-conducting zones in a coastal region. Low-resistance sea water penetrates and forms zones of high conductivity and high dielectric constant along the coast. The geoelectrical relations in coastal regions are thus substantially more complicated than assumed by many authors in their treatment of the so-called "coast effect" [Doluchanov, 1956], which is a change of propagation conditions in coastal regions. Frequently, both salt water and fresh water strata exist underground. The specific resistivity of salt water is usually far below 1 ohmmeter. In figure 4 an interesting structure is shown, where water of normal conductivity rises from a deep fresh water stratum, traverses a weak salt water stratum and forms a "cloud" above it. Thus, zones of normal or even of low conductivity suddenly appear to be contained within extremely well-conducting zones.

All of these examples are very schematic; conditions in nature are still substantially more complicated.

Besides the horizontal structure outlined, there is almost always a characteristic vertical structure. The latter is determined especially by tectonic influences. Note in figure 5 how the underground structure is disturbed by a fault. Such structures are by no means an exception, but can almost always be considered the rule. The existence of disturbances, however, always influences propagation very strongly, as we shall see later on. 


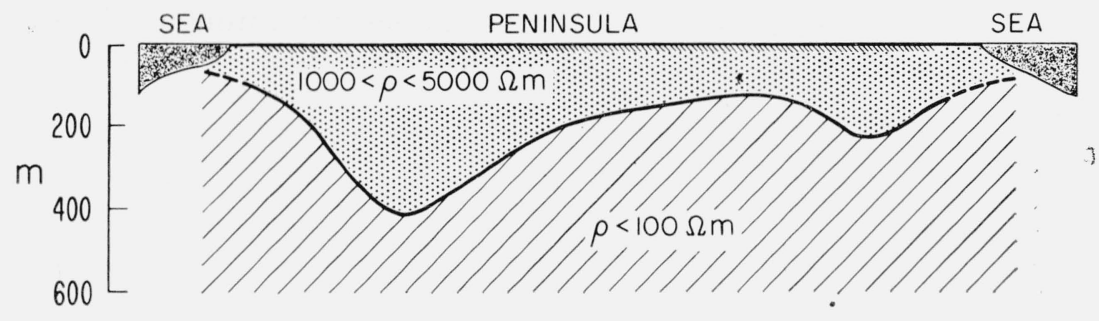

Figure 3. Geo-electrical structure of a coastal region.

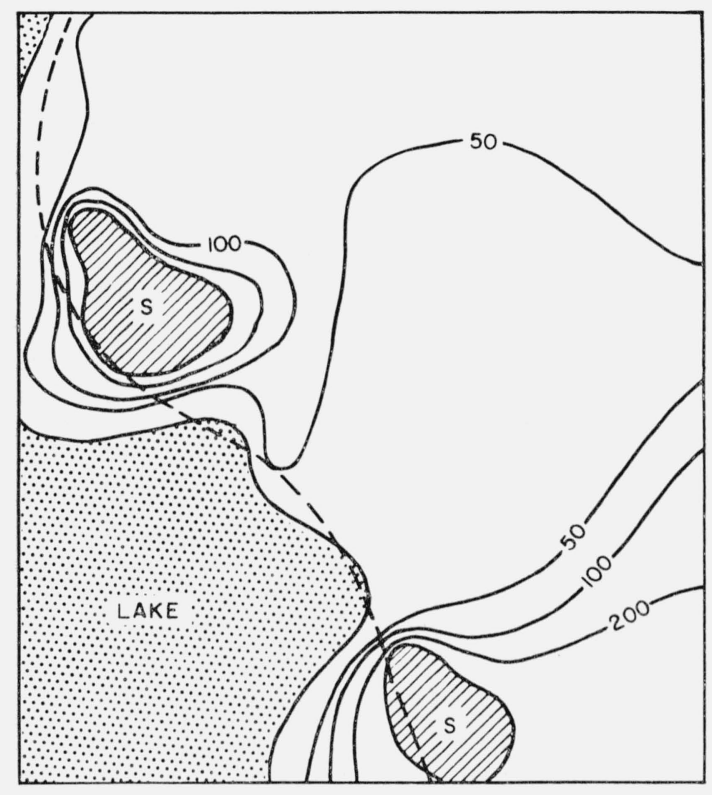

SPECIFIC RESISTIVITY OF THE GROUND

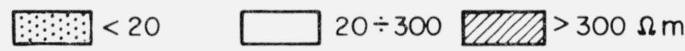

$S=$ FRESH WATER COLUMNS

-50- = RESISTANCE CONTOURS IN $\Omega \mathrm{m}$

Figure 4. Fresh water columns.

\subsection{Conductivity and Dielectric Constant}

Every geological conductor consists of parts pertaining to all three states of matter. Electrically, geological material consists mostly of a dielectric solid mineral, in which are situated ohmic conducting regions (mostly liquid or amorphous) and air-filled spaces.

In almost every geophysical handbook [Löwy, 1911; Fritsch, 1960], one finds tables which indicate resistivity and dielectric constant of various geological substances. However, these can constitute only approximate mean values, which are not adequate for a complete evaluation of propagation measurements. Rather, it is necessary to determine the resistivity values of rocks by special measurements.

In calculating the electrical properties of geological conductors, the following has to be observed:

Every geological conductor is an aggregate whose electrical constitution depends on the resistivity and dielectric constant values, $\sigma$ and $\epsilon$, of the individual components as well as on their relative volumes, $\theta$. From these, one may calculate the electrical properties of the aggregate by means of several mixing theories. The solid portions usually have very high resistivity (up to $10^{6}$ ohmmeters, or more). Several types of ores are exceptions having extremely low resistivity, but these occur only rarely. The dielectric constant is mostly between 6 and 12, apart from the ore types mentioned.

Among the liquid components, solutions in water are of importance, and, in a few exceptional cases, in oil. Chemically pure water is almost an insulator, but even very weak concentrates reduce its resistivity

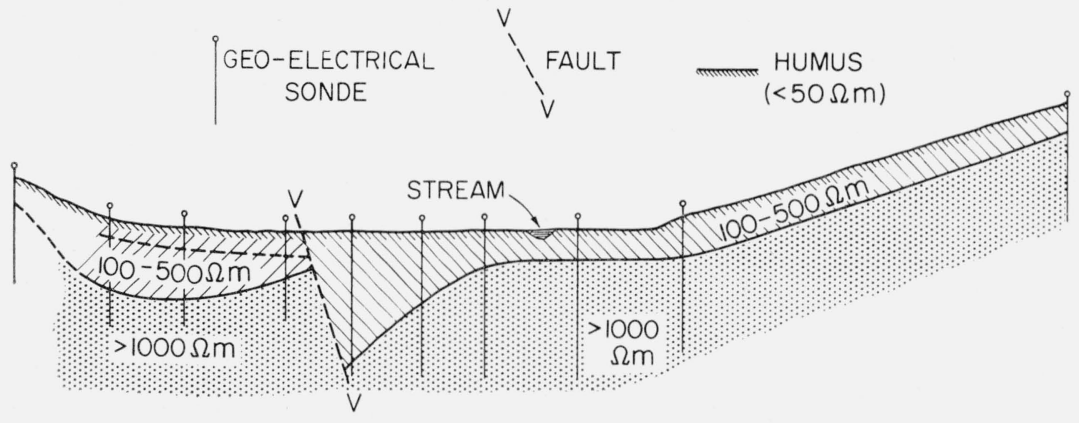

Figure 5. Fault zones. 
considerably. Solutions found in mountains have resistivity values between 20 and 100 ohmmeters if nonsaline. Salt water, however, can have a value of resistivity less than $10^{-3}$ ohmmeters.

The known dielectric constant of pure water is 81 , but it can be substantially increased by the addition of only small amounts of mineral solutions. One has to consider a dielectric constant of 2 for oil, and between 1 and 1.5 for carbon dioxide solutions, as for instance contained in potash deposits.

In calculating aggregates, one naturally has to consider the "bound" water (for instance, in clays), whose resistivity is very low most of the time. The conductivity of gaseous inclusions can be neglected, even if they are ionized.

Although empirical laws are preferred by some, the best results, in the author's opinion, are produced by mixing theories. Specifically, for rock of low moisture content, the theory of Lorentz and Lorenz [1880], and, for rocks of high moisture content, the theory of Lichtenecker [1924], is applicable. Other rules have been given by Wiener [1912], Hummel [1935], and Krajew [1957]. Results are often substantially affected by the angle between the measurement direction and the plane separating media with different geo-electrical properties (effect of anisotropy).

If the resistivity values of the two components of the aggregate are denoted $\rho_{1}$ and $\rho_{2}$, and their relative volumes are $\theta_{1}$ and $\theta_{2}$ (with $\theta_{1}+\theta_{2}=1$ ), one obtains the following for the resistivity of the aggregate, in accordance with Lorentz and Lorenz [1880]:

with

$$
\rho_{0}=\frac{1-A}{2 A+1}
$$

and

$$
\left.\begin{array}{c}
A=\theta_{1} f\left(\rho_{1}\right)+\theta_{2} f\left(\rho_{2}\right) \\
f\left(\rho_{1}\right)=\frac{1-\rho_{1}}{1+2 \rho_{1}} \text { and } f\left(\rho_{2}\right)=\frac{1-\rho_{2}}{1+2 \rho_{2}}
\end{array}\right\}
$$

Analogously, one obtains the dielectric constant, $\epsilon_{0}$, of the agrogregate:

with

$$
\epsilon_{0}=\frac{2 B+1}{1-B}
$$

and

$$
\left.\begin{array}{c}
B=\theta_{1} f\left(\epsilon_{1}\right)+\theta_{2} f\left(\epsilon_{2}\right) \\
f\left(\epsilon_{1}\right)=\frac{\epsilon_{1}-1}{\epsilon_{1}+2} \text { and } f\left(\epsilon_{2}\right)=\frac{\epsilon_{2}-1}{\epsilon_{2}+1}
\end{array}\right\}
$$

In accordance with Lichtenecker [1924], one obtains:

and $\left.\quad \begin{array}{l}\log \rho_{0}=\theta_{1} \log \rho_{1}+\theta_{2} \log \rho_{2} \\ \log \epsilon_{0}=\theta_{1} \log \epsilon_{1}+\theta_{2} \log \epsilon_{2}\end{array}\right\}$
Equations (7) through (9) may of course be expanded in a simple manner so that aggregates having more components can also be considered.

Naturally all values calculated in this manner apply only to direct or low frequency alternating current.

\subsection{Frequency Effects and the Equivalent Circuit}

In our investigations we must always consider that radiofrequencies are used. Principally, the Debye and the Onsager effects, the displacement of field lines, and also the Wien effect have to be taken into account [Mueller, 1950]. The Debye effect is defined as a decrease of the resistivity of an electrolyte with increasing frequency, and the Wien effect as a decrease of resistivity and dielectric constant with increasing voltage. Both effects also depend on temperature and pressure; this in turn is known as the Onsager effect. All these phenomena tend to counteract each other: resistivity decreases with increasing frequency, but at the same time the current density is reduced, resulting again in an increase of the resistivity. As the dependence of resistivity on frequency furthermore increases with increasing pressure and temperature, additional complicated relations to depth result in the treatment of largescale phenomena. At the present time, comprehensive experimental material for a concise treatment of this problem is still lacking; it has a decisive influence on the calculation of all propagation phenomena below the surface of the earth. Naturally, because of it, the attenuation also becomes a much more complicated function of frequency than indicated by eq (4).

The approximate equivalent circuit of a geological conductor is shown in figure 6 . The general equivalent circuit shows the resistive and the inductive component in series, and the capacitive component is in parallel to both. As both the resistive and the capacitive components are much stronger, the inductive component may usually be neglected. If the underground strata consist of plane parallel layers which conduct principally alternately resistive and capacitive, different equivalent circuits are obtained at right angles and parallel to the stratification.

The values $R_{g}, L_{g}$, and $C_{g}$ given in the equivalent circuit are frequency dependent. Thus an equivalent circuit for a geological conductor drawn for a given frequency is valid only for this frequency, or a given frequency band.

Almost all sediments and schists are classified stratified conductors. Even the topmost layer of the earth is a stratified medium, if regarded in its entirety. In this case the angle between the direction of the current vector and the plane of stratification is important. Wiener [1912] has attempted to take this angle into account in the definition of a "transmission factor" varying between zero and infinity.

Figure 7 shows how strongly stratification affects even the ohmic resistance. The curves shown here were determined by the author from large-scale 
ferent geological conductors, and a mixture formed by the two, respectively. A concrete sample is tested, representing an inhomogeneous material (fig. 8). Concrete consists of cement, quartz sand, and coarse-grained additives. From the geo-electric point of view, it may be compared to a very inhomogeneous coarse-grained conglomerate. The resistivity decreases with frequency as postulated by the Debye effect. The dielectric constant shows anomalies in the region below $2 \mathrm{Mc} / \mathrm{s}$, and decreases with increasing frequency above this value. The curves shown apply to two different amounts of moisture content $(\theta=4.8$ and $1.4 \%)$. The higher the content of pore water solution, the weaker the dependence of resistivity on frequency.

In contrast, figure 9 shows the corresponding diagrams for a very homogeneous geological conductor, fine-grained marble. The trend in dielectric constant and the resistivity, $\rho^{\prime}$, is similar to that shown in figure 8. However, the dielectric constant curve does not show the extremes in the region below 2 $\mathrm{Mc} / \mathrm{s}$; rather, both the $\rho$ and the $\epsilon$ curves rise continuously with decreasing frequency. ${ }^{2}$ Naturally, the absolute resistance values are very different. The dielectric constant of marble is somewhat lower than that of concrete, and the resistivity of marble is higher. It is to be noted that the marble sample investigated had remained in water for several days so that its water content $(0.774 \%)$ was relatively high.

In order to obtain the attenuation in accordance with eq (2), we must not only take into account the frequency relations expressed by eq (4), but we have to substitute the values, $\epsilon_{g}^{\prime}$ and $\sigma_{z}$, themselves again into eq (4) as frequency-dependent quantities. The attenuation to be substituted in eq (1) is furthermore influenced by the electrical structure of the underground conductors and by additional effects such as field line displacement. As an example, one should therefore not be surprised if, as we shall see later on, the dependence of $E_{z} / E_{0}$ on frequency is represented by an extremely complicated function whose trend does not always correspond to that given by eq (1) and the subsequent equations.

The effective electrical properties of the ground at low frequencies have also been investigated by Wait [1957].

\subsection{The Earth as a Geological Conductor}

If we do not want to forego the theoretical treatment of the problem in spite of these complications, we have to decide on the use of extensive schematization. A correct choice for such a scheme or model determines whether or not experimental results can be explained theoretically.

For propagation measurements along the surface of the earth, the resistivity and the dielectric constant are usually given for an "effective layer thick-

$2 \mathrm{~J} . \mathrm{R}$. Wait is of the opinion that the drop in the curve in the region above 1 $\mathrm{Mc} / \mathrm{s}$ is due to the measurement technique, as he has observed an increase in the same region. ness." If one plots the amplitude of field strength as the ordinate versus the depth of penetration as the abscissa, and determines the area between this curve and the coordinate axes by means of a planimeter, an "effective layer thickness" is readily obtained. This parameter is a function of frequency, resistivity, dielectric constant, and underground geo-electrical structure. It cannot be defined exactly in a physical sense; in practice one takes it to be that depth where geo-electric inhomogeneities of sufficient extent still influence the measurement results. It can also be thought of as that depth where the field radiated from the surface is strong enough to permit its measurement with sufficient accuracy under usual noise conditions.

As we have seen, the resistivity of a geological conductor generally decreases with frequency. If, however, the underground is stratified, the opposite is also possible. Let us assume that the underground consists of relatively poorly conducting sand and gravel, containing a ground water pool. The ground water base, of course, has a much lower resistivity than the overburden. For low frequencies, the effective layer thickness will extend into the ground water. If frequency is increased, penetration dedecreases, and extends only into the poorly conducting overburden. In this case, effective conductivity decreases with frequency [Grosskopf and Vogt, 1941]. Similar phenomena can also be observed whenever the surface strata freeze.

The mean resistivity values which can be calculated from propagation measurements [Wise, 1930], may therefore often produce a completely wrong picture of the actual geo-electrical ground structure. Thus, when confronted in 1961 with the task of compiling a geo-electrical description of Austria, posed by the Austrian Federal Ministry for Traffic and Electricity Administration, the author decided to use an electrical schematization, instead of a single value. This schematization is reproduced in the following table, and the zones listed in the table are illustrated in figure 10.

It would be advantageous if one would generally consider this characterization of the underground when evaluating propagation measurements. The problem becomes substantially clearer, if mean values for large depths are developed. One can then distinguish three zones: The first layer is in homogeneous and relatively well conducting; its geo-electrical properties are determined by the existence of contained water. The second layer is formed by homogeneous and poorly conducting rocks, extending practically as deep as the Mohorovicic discontinuity. Below this layer, conductivity increases and finally attains extremely large values; above, boundary layers of sediments, granite, etc., occur.

In the region between the deepest ground-water levels and the Mohorovicic discontinuity, one can expect resistivity values of $10^{8}$ ohmmeters. Thus, attenuation in this region is small.

The special radiogeological assumptions for Karstic limestone caves, potash deposit, ores, and coal mines will be discussed later on. 


\begin{tabular}{|c|c|c|c|c|}
\hline \multirow{2}{*}{ Zone } & \multirow{2}{*}{ Geological characteristics } & \multirow{2}{*}{ Overburden } & \multicolumn{2}{|c|}{ Bedrock } \\
\hline & & & Resistivity & Homogeneity \\
\hline 1 & $\begin{array}{l}\text { Principally Bohemian Mas- } \\
\text { siv (granites, ortho- and } \\
\text { paragneisses, crystalline } \\
\text { schists). }\end{array}$ & $\begin{array}{l}\text { Erosion layers; very inho- } \\
\text { mogenous in material } \\
\text { and thickness. Com- } \\
\text { pletely missing in some } \\
\text { places. }\end{array}$ & $\begin{array}{l}\text { Varies within extremely large } \\
\text { limits from very low values } \\
\text { (f.i. graphite) up to maxima } \\
\text { of } 10^{4} \text { ohmmeters or greater. }\end{array}$ & $\begin{array}{l}\text { Very pronounced frag- } \\
\text { mentation of the bed- } \\
\text { rock. }\end{array}$ \\
\hline 2 & $\begin{array}{l}\text { Pre-cambrian crystalline } \\
\text { schists, Paleozoic, princi- } \\
\text { pally calcareous-dolomitic } \\
\text { sediments, covered mostly } \\
\text { by stream gravels. }\end{array}$ & $\begin{array}{l}\text { Inhomogenous talus, com- } \\
\text { pletely missing in some } \\
\text { places. }\end{array}$ & $\begin{array}{l}\text { Varies within very large limits } \\
\quad(\text { similar to Zone } 1) \text {. }\end{array}$ & $\begin{array}{l}\text { Very pronounced frag- } \\
\text { mentation of the bed- } \\
\text { rock. }\end{array}$ \\
\hline 3 & $\begin{array}{l}\text { Central granite and central } \\
\text { gneiss, crystalline schists } \\
\text { of the schist envelope and } \\
\text { graywacke zone, covered } \\
\text { by stream gravels. }\end{array}$ & $\begin{array}{l}\text { Inhomogenous talus, com- } \\
\text { pletely missing in some } \\
\text { places. }\end{array}$ & $\begin{array}{l}\text { The resistivity of the rock } \\
\text { varies in general between } \\
\text { relatively higher values } \\
\left(10^{3}-10^{4} \text { ohmmeters }\right) \text {. }\end{array}$ & $\begin{array}{l}\text { Very pronounced frag- } \\
\text { mentation of the bed- } \\
\text { rock. }\end{array}$ \\
\hline 4 & $\begin{array}{l}\text { Limestones, dolomites, } \\
\text { marls of the calcareous } \\
\text { alps, stone and clay marls } \\
\text { of the Flysh zone, parti- } \\
\text { ally covered by stream } \\
\text { gravels. }\end{array}$ & $\begin{array}{l}\text { Quite inhomogenous talus } \\
\text { in the calcareous alps, } \\
\text { little homogeneous in the } \\
\text { Flysh zone. Mostly pre- } \\
\text { dominantly clayey in } \\
\text { Flysh. In limestone the } \\
\text { overburden is missing in } \\
\text { places. }\end{array}$ & $\begin{array}{l}\text { Relatively homogeneous re- } \\
\text { sistivity: mostly } 1000-5000 \\
\text { ohmmeters in limestone } \\
\text { alps and } 100-1000 \text { ohm- } \\
\text { meters in Flysh. The geo- } \\
\text { electrical rock structure is } \\
\text { more homogeneous in lime- } \\
\text { stone than in Flysh. }\end{array}$ & $\begin{array}{l}\text { Very pronounced frag- } \\
\text { mentation of the bed- } \\
\text { rock. }\end{array}$ \\
\hline 5 & $\begin{array}{l}\text { Clays and sands of the re- } \\
\text { cent Tertiary, partially } \\
\text { with some Quaternary } \\
\text { overburden. }\end{array}$ & $\begin{array}{l}\text { Relatively homogeneous } \\
\text { talus and stream gravel } \\
\text { cover. }\end{array}$ & $\begin{array}{l}\text { Relatively homogeneous } \\
\text { structure with resistivity } \\
\text { values of } 50-500 \text { ohm- } \\
\text { meters. }\end{array}$ & $\begin{array}{l}\text { Mostly weak fragmen- } \\
\text { tation of the bedrock. }\end{array}$ \\
\hline 6 & $\begin{array}{l}\text { Principally clays of recent } \\
\text { Tertiary, with Quaternary } \\
\text { overburden. }\end{array}$ & $\begin{array}{l}\text { Homogeneous stream grav- } \\
\text { el covering. }\end{array}$ & $\begin{array}{l}\text { Large-area homogeneous } \\
\text { structure with resistivity } \\
\text { values of } 50-200 \text { ohm- } \\
\text { meters. }\end{array}$ & $\begin{array}{l}\text { Mostly weak fragmen- } \\
\text { tation of the bedrock. }\end{array}$ \\
\hline 7 & $\begin{array}{l}\text { Crystalline schists deeply } \\
\text { underground, covered by } \\
\text { Tertiary conglomerates } \\
\text { and Quaternary forma- } \\
\text { tions. }\end{array}$ & $\begin{array}{l}\text { Genetically different, but } \\
\text { petrographically homo- } \\
\text { geneous gravel covering. }\end{array}$ & $\begin{array}{l}\text { Large-area homogeneous } \\
\text { structure with resistivity } \\
\text { values of } 500-5000 \text { ohm- } \\
\text { meters. }\end{array}$ & $\begin{array}{l}\text { Mostly weak fragmen- } \\
\text { tation of the bedrock. }\end{array}$ \\
\hline 8 & $\begin{array}{l}\text { Clays and sands of the re- } \\
\text { cent Tertiary, almost } \\
\text { always covered by Qua- } \\
\text { ternary. }\end{array}$ & $\begin{array}{l}\text { Homogeneous stream grav- } \\
\text { el covering. }\end{array}$ & $\begin{array}{l}\text { Very large-area homogeneous } \\
\text { structure with resistivity } \\
\text { values of } 50-200 \text { ohm- } \\
\text { meters, in Burgenland prov- } \\
\text { ince, extensive zones in } \\
\text { the vicinity of Lake Neu- } \\
\text { siedl with low resistivity } \\
\text { values ( }<20 \text { ohmmeters). }\end{array}$ & $\begin{array}{l}\text { Fragmentation of the } \\
\text { bedrock weak. }\end{array}$ \\
\hline
\end{tabular}

Translator's Note: The expressions "schist envelope," "calcareous alps," and "Flysh zone" pertain to alpine geology; no equivalent terms exist in American geology.

\section{Experimental Treatment of the Problem}

\subsection{Transmitters, Receivers, and Antennas}

Transmitters used for geo-electric investigations have been described by Tarkhov [1955], Fritsch
[1949], Pritchett [1952], and others. Receivers have to be especially sensitive in order to allow measurements even in the presence of substantial attenuation. A suitable circuit is given by Grosskopf and Vogt [1940]. Sensitivity has to be pushed to the limit imposed by resistor and tube noise. 


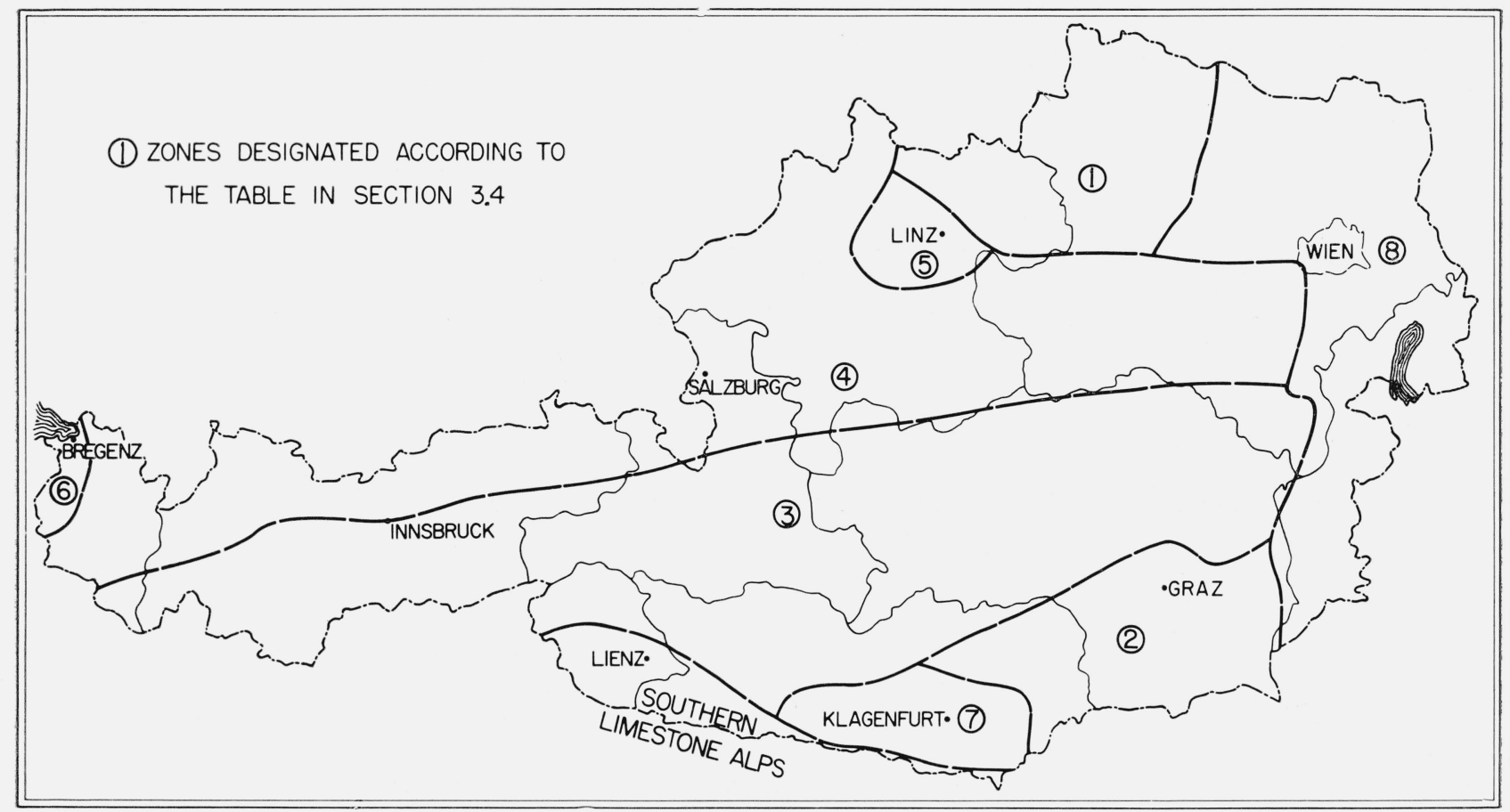

Figure 10. Geo-electrical map of Austria.

Selection of the correct antenna type is often difficult. If one ignores the possibility of large subsurface cavities where conventional antennas could be installed, the use of ground antennas is mandatory [Doluchanov, 1956]. For physically longer receiving antennas one has to take into account attenuation through the adjacent rock. There is no point in exceeding a definite length given by frequency, distance from the rock, and the electrical properties of the rock.

The question whether long wire or loop antennas are to be used was investigated by Petrovsky et al. [1930]. Unfortunately, general rules are difficult to establish. However, the use of ferrite loop antennas has advantages, as these can be constructed in small sizes. Letting $l$ be the length and $D$ the diameter of the ferrite rod; $W$ the number of turns of the coil wound on it; $Q \cong \frac{\omega L}{R}$ the $Q$ of this coil, and $\mu_{0}$ the relative permeability, one obtains

$$
U_{\mathrm{o}}=\omega H_{\mathrm{o}} A \mu_{\mathrm{eff}} 10^{-8} \text { volts }
$$

for the peak value, $U_{0}$, of the voltage induced in the winding, with $H$ being the magnetic field strength induced by the transmitter at the receiving location. With $L$ being the self-inductance, and $R$ the resistance of the coil:

and

$$
A \simeq 5 D^{2} W L R^{-1} f,
$$

$$
\mu_{\mathrm{eff}}=\frac{\mu_{\mathrm{o}}}{1+1.8 \frac{D^{2}}{l^{2}}\left(\mu_{\mathrm{o}}-1\right)} .
$$

One may substitute approximately 200 for $\mu_{0}$.
However, it has been shown by experiments that electromagnetic energy frequently arrives underground from various directions, and that these paths do not always coincide with the straight line connecting transmitter and receiver. This has to be taken into account when using loop antennas.

\subsection{Noise}

Atmospheric noise can usually be neglected underground. With a more extensive overburden, noise intensities are reduced to values of $10^{-8} \mathrm{volt} / \mathrm{m}$, or less.

On the other hand, noise in mines and illuminated limestone caves may be generated by electric currents and arc lights. This was investigated by Burgholz [1944] and others.

\subsection{Measurements in Potash Deposits}

[Barrett, 1952; Fritsch, 1948]

The most favorable propagation conditions exist in salt and potash deposits. The resistivity values of these deposits are mostly between $10^{8}$ and $10^{12}$ ohmmeters. However, only very small traces of moisture (0.001 of a percent of volume) increase conductivity substantially.

If one conducts propagation measurements in potash deposits, one must not overlook the fact that the deposit is bounded at the top and bottom (the "roof" and the "floor") by rock zones of substantially higher conductivity. Figure 11 shows a schematic diagram of such a deposit, substantially exaggerated in a vertical direction. The distance between transmitter and receiver ranged up to 10 $\mathrm{km}$, and the depth of the terminal locations down to 300 to $400 \mathrm{~m}$. The overburden just beneath a layer 


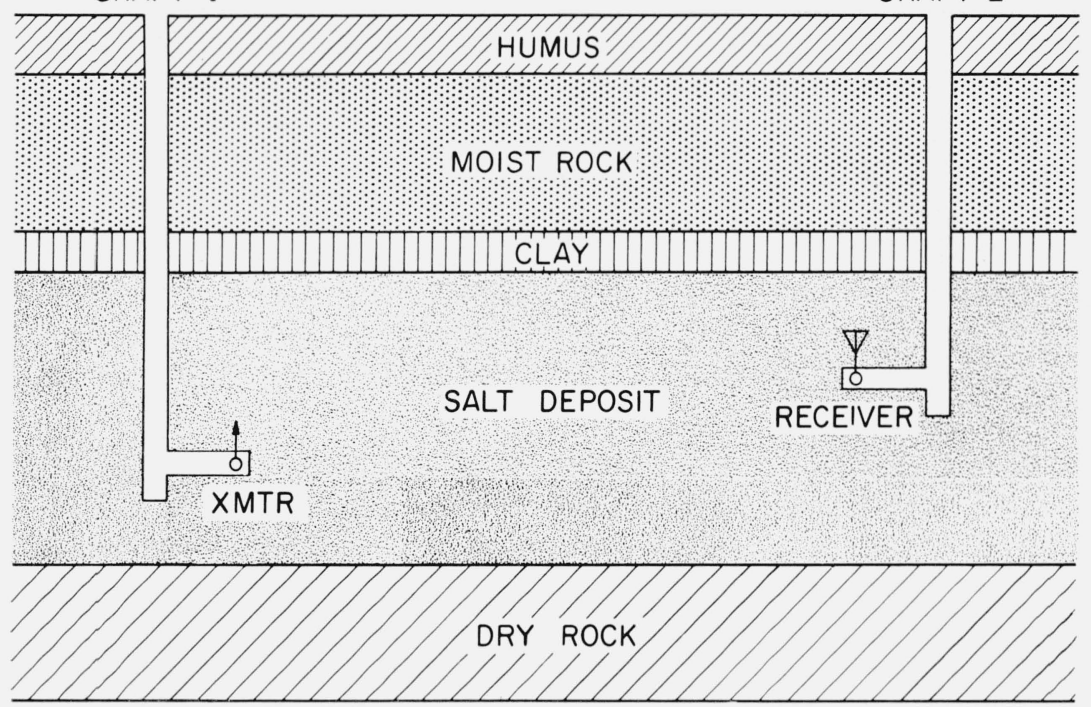

Figure 11. Schematic diagram of a potash deposit.

of sod has resistivities in the range 500 to 1500 ohmmeters. Between overburden and salt deposit is a clay layer which shields the deposit against moisture penetrating in a vertical direction. Its resistivity is often reduced to values of 50 ohmmeters or less. Below the salt deposit there are relatively dry rock strata having resistivity values mostly between $10^{3}$ and $10^{4}$ ohmmeters.

Figure 12 shows a schematic cross section through a deposit, where the author conducted extensive investigations. Two quite thick deposits are situated in the relatively conductive schist. The overburden above the top deposit is moister than the rock below it; thus, its resistivity is less by one order of magnitude.

Although these deposits are usually considered to be completely homogeneous, a definite electrical structure is apparent, which is called "ribboning." The dielectric constant in particular depends on the angle included between the direction of measurements and the plane of the deposit.

Every minor fold, as well as pinching out of the deposit (even if only on a small scale), influences propagation in a very marked manner. For example, the author (as will be mentioned again) achieved ranges up to $14 \mathrm{~km}$ in the Hannover potash deposits, parallel to the Leine River. However, in a direction at right angles, it was not possible to bridge the shorter distances toward the Hildesheim mines. In the opinion of geologists, a fault fissure, or a zone of variegated sand stone, exists at right angles to this direction, explaining this result.

Sometimes (for instance, in the German Werra Mines) gypsum deposits occur within the overburden, resulting in extremely conductive solutions $\left(10^{-3}\right.$ to $10^{-6}$ ohmmeters). These solutions migrate through fissures and joints in the rocks so that the rock conductivity is increased by a considerable amount. In this case, the deposit is practically shielded toward the top when measuring propagation.
Any break in the shale bed above the salt beds, even if only minor, permits penetration of moisture into the deposit, and a sharp decrease in its resistivity to values of $10^{-2}$ ohmmeters or less. These zones then act as shields in propagation measurements.

In mines having good ventilation, a wet and very conductive thin film is formed at the surface of the tunnels, but has little disturbing effect. Sometimes, however, its effect is stronger, as with strongly hygroscopic carnalite. Therefore, it is best to con-

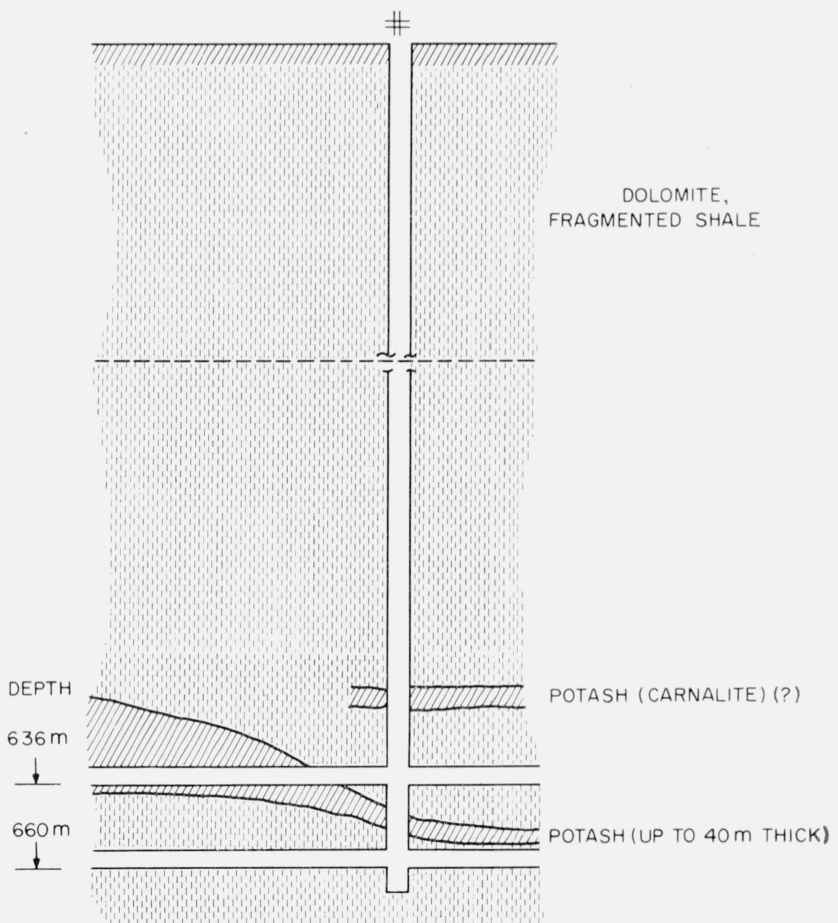

Figure 12. Cross section through a potash deposit (Werra region). 
duct propagation experiments in mines with poor, or no artificial, ventilation.

\subsection{Measurements in Karst Caves}

Joyce [1931]; Stern [1931]; Fritsch [1932]; Doborzyński [1936, 1937]; Fritsch [1939].

The earliest propagation measurements were conducted in Karst caves. Large caves are generally well suited for such investigations, as longer antennas and large loops can be easily installed.

However, certain difficulties have to be taken into account. The rock structure is usually strongly jointed. After all, the origin of the caves is connected with tectonic disturbances. The conductivity of these zones is usually much greater than that of undisturbed formations. Therefore, one must always consider extensive geo-electrical heterogeneous layers immediately adjacent to the caves. These influence the propagation of radiofrequency electromagnetic fields much more than the cavities themselves. Figure 13 shows a typical Karst cave system, in cross section, where the author has conducted numerous measurements [Fritsch, 1932]. The surface opening is designated by $M$, the subterranean cave chain by $H$, and $E$ shows a very large collapsed cave. The floor of the caves is often covered by completely moist loam. Its resistivity is on the order of 20 to 40 ohmmeters, and is thus substantially below that of naturally wet limestone. The walls of the caves are also often covered by cave loam. This is of significance when very short waves are considered. The propagation of waves in long caves of small cross section is then often effected in a manner similar to that in waveguides. Effects similar to those observed by the author in narrow river valleys [Fritsch, 1933], or by Polic [1944] in his model experiments, can be noted.

The question whether radiofrequency electromagnetic fields penetrate through the surface opening of a cave was investigated by several authors. For larger distances from the opening, one may surely neglect the field component directly radiated through the opening.

\subsection{Measurements in the Vicinity of Ore and Coal Deposits}

Petrovsky [1908]; Fritsch [1936, 1937]; Wadley [1946]; Jung [1950]; Felegy [1953].
With few exceptions, the conductivity of ore and coal deposits is not higher than that of the adjacent rocks. In some cases the resistivity of the deposit is even greater than that of the host rock. For example, a siderite vein is usually less conductive than moist schist.

In spite of this, deposits of sufficiently large area have a considerable influence on the formation of electromagnetic fields. The following are approximate reasons:

(a) The deposit usually separates zones of geological conductors having different resistivity values. The rock above the deposit (the "roof") is often moister and therefore has a smaller resistivity, even if petrographically very little different from the rocks below the deposit (the "floor").

(b) In the boundary layer between the deposit and the rock, water content is often greater than in other rock. The concentration and conductivity of such fissure waters are mostly dependent on the chemical constitution of the deposit. In any case, a zone of increased conductivity in rock is generated by greater water content.

If the deposit consists of certain sulifde or oxide ores, or of coal having substantial thickness, it naturally influences propagation of the fields directly; otherwise, its influence is indirect. Hence, it is understandable that many deposits exercise their influence on the propagation of the fields even after they have been extensively depleted. The space which they occupied earlier is usually filled with barren rock. The interstices in this fill are naturally substantially larger than those of the surrounding rocks, and are also much more saturated with watery solutions caused by the moisture always present in rocks and mines. Thus, already depleted and filled deposits may often have less resistivity than those which have not been depleted.

Figure 14 shows a cross section through a coal mine. The coal seams are being worked in two tunnels (10th and 11th tunnel). The rocks consist of carbonaceous schists and sandstones which, under conditions of natural rock moisture, have approximately the same resistivity values as the coal itself, or sometimes lower. The overburden consists principally of marl, also conductive. In this case, the mine structure is extensively shielded electrically. The ranges to be expected can only be small.

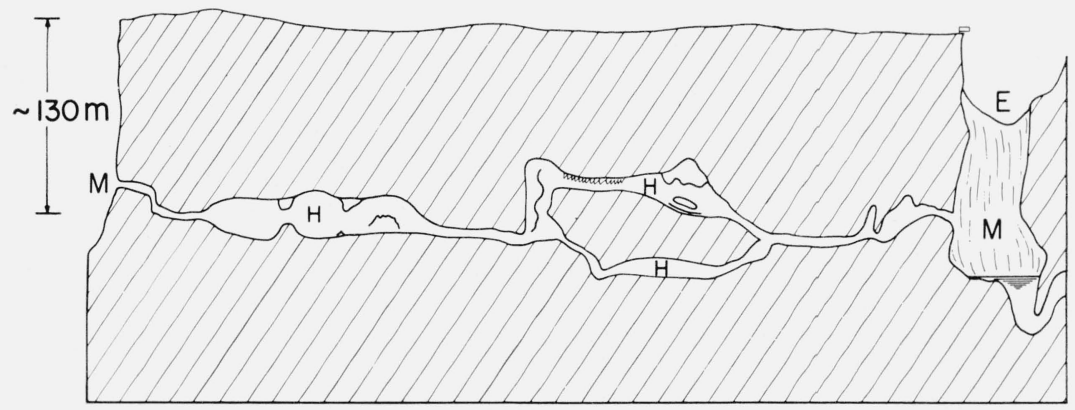

Figure 13. Cross section through a Karst cave system. 


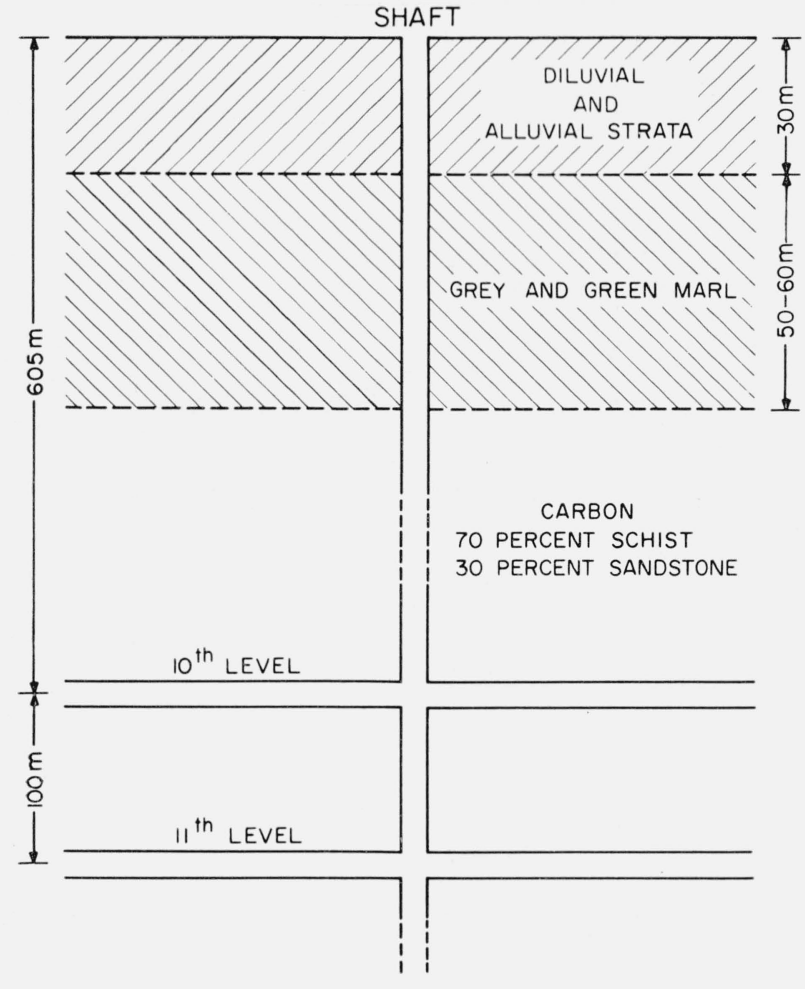

Figure 14. Cross section through a coal mine.

In figure 15 , we see a cross section through an iron mine, where the author has also made studies. The limestone rock has resistivity values of several thousand ohmmeters. Gray copper ore seams which have been mined out and backiflled have substantially less resistivity because of their higher water content. In the vicinity of the surface opening, $A$, the first tunnel penetrates through a fault zone, L, having less resistivity. In this case, it was possible to prove that the fields radiated from a transmitter, located at point $\mathrm{B}$, through the rocks can be still measured at point $\mathrm{C}$. In the direction from $\mathrm{B}$ toward $\mathrm{A}$, the field strength of the transmitter at B decreased slowly at first, but very rapidly after passing through layer L. Thus, no reception was possible at A. However, good reception was possible at point $\mathrm{C}$ and immediately below the humus layer, between $\mathrm{C}$ and D.

\subsection{Other Measurements}

In addition to tunnels and drifts in mine installations and caves, investigations of the kind described were conducted using railroad tunnels. For example, the author has conducted propagation experiments toward an old mine tunnel, using the approximately 8-km-long Tauern (railroad) tunnel in Austria [Fritsch, 1952]. In all such investigations, special additional measurements are necessary in order to determine whether the rails or overhead wires influence the test results. In accordance with the author's experience, the rails, if installed on a moist roadbed, have only a small effect on propagation. However, electrical overhead wires interfere strongly. One has to disconnect these wires from those outside the tunnel portal, and furthermore, one has to ground the wires to the rails at various places inside the tunnel.

\subsection{Effect of Industrial Conductors}

Measurement results are unfortunately almost always influenced by the numerous industrial conductors which are found inside caves, mines, and tunnels, leading out to points on the earth's surface.

These conductors (electrical wiring, tubing, rails, hoisting cables, etc.) guide the fields, simulating very long ranges in certain directions. Thus, for example, reports on extremely long ranges in coal mines [Stipanits, 1938] are incorrect because the effect of the hoisting cables was not taken into account.

As one almost always has to count on the presence of industrial conductors, their effect must be evaluated by additional measurements, and then suppressed by disconnecting, grounding, or installation of filters wherever this is possible [Fritsch, 1939].

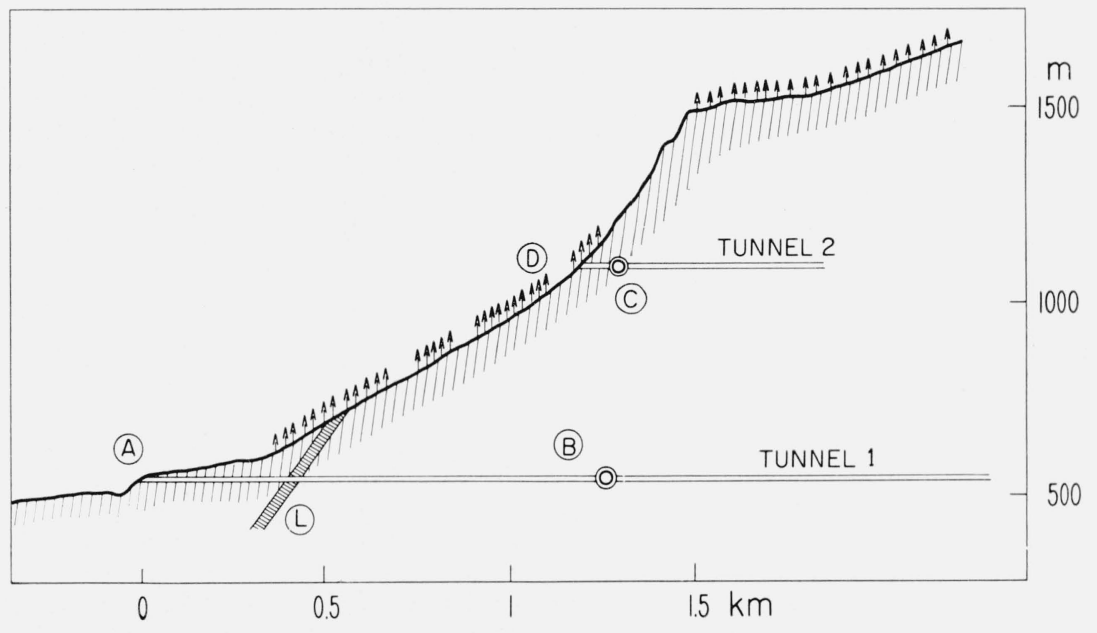

Figure 15. Cross section through an iron mine. 


\section{Important Results}

\subsection{Ranges Obtained}

Smith-Rose and Barfield [1926]; Eve [1932]; Fritsch [1942]; Haycock, Madsen, and Hurst [1949]; Bays [1952].

Especially long ranges are possible in potash deposits. Figure 16 shows ranges (which the author obtained in the Werra mines in Thuringia, Germany) in kilometers. The investigations were conducted using transmitters with frequencies between 2600 and $3500 \mathrm{kc} / \mathrm{s}$. The longest range was attained between the potash mines, Godenau and Freden, in Hanover province (Germany). There, the distance between transmitter and receiver amounted to approximately $14 \mathrm{~km}$.

In other rocks, ranges obtained so far are naturally much smaller. In coal-bearing rocks, maximum ranges obtained are between 300 and $600 \mathrm{~m}$; in ore-bearing rocks, ranges up to $2000 \mathrm{~m}$ were obtained. Humus, loam, and clay strata absorb the fields so strongly that ranges of only a few meters, or sometimes of only tenths of meters are possible in them. In figure 17 we see the decrease in the field strength, $\bar{E}$, if $\bar{E}_{0}$ is the field strength in the immediate vicinity of the transmitter, and $S$ is the distance from the transmitter. Diagram (a) refers to only moderately moist and relatively solid limestone; diagram (b) refers to the same rock, which in this case, however, is covered by a humus and erosion layer only approximately $2 \mathrm{~m}$ deep. This test was conducted using a wavelength of $60 \mathrm{~m}$.

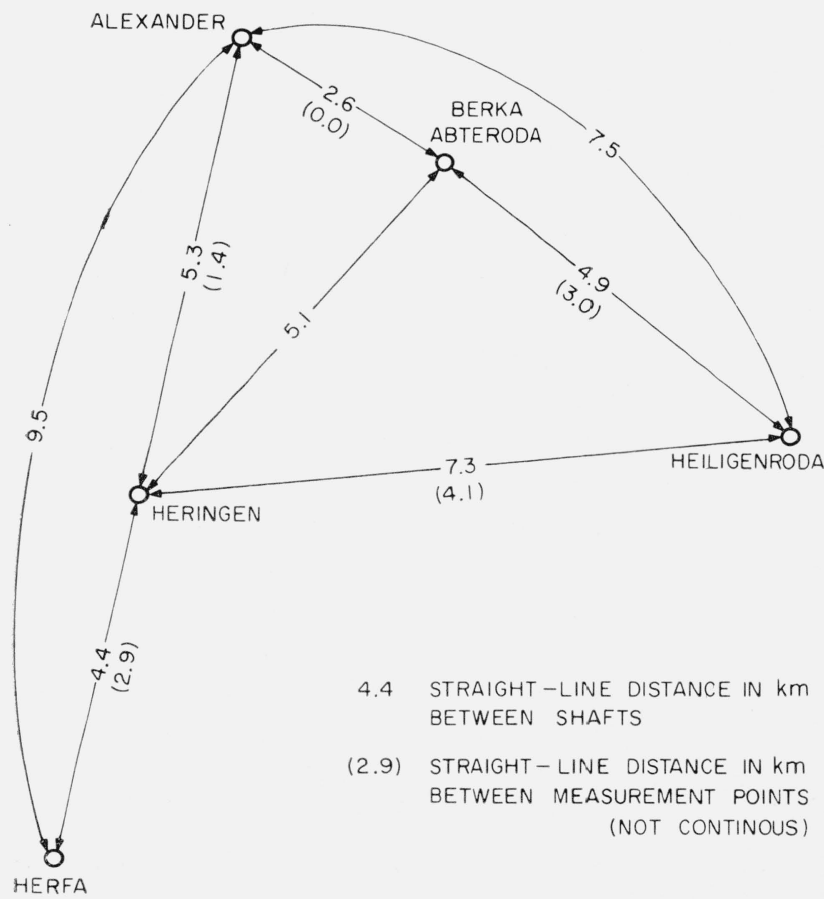

FiguRe 16. Obtained ranges in potash deposits.

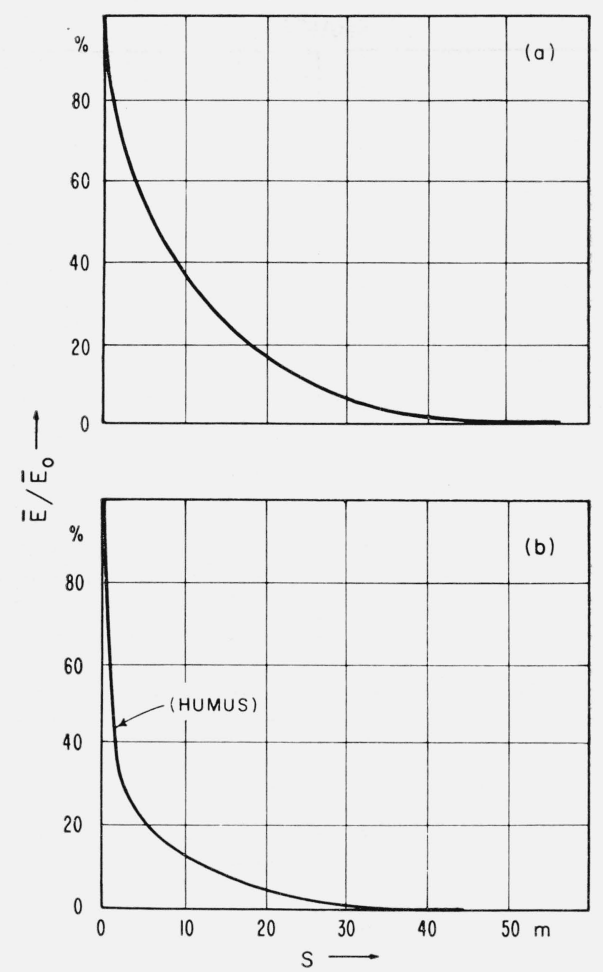

Figure 17. Field strength curves.

One perceives that the decrease in field strength in humus layer is very steep. In very well-conducting strata, e.g., in moist clays, ranges approach those calculated by Brüne [1937] for water. The high attenuation of the topmost erosion layer often induces the belief that only very small ranges are possible in the interior of the earth; whereas, in fact, the much smaller attenuation rate of firm rocks makes much longer ranges possible.

It is thus evident that ranges attained to date can be still increased. Means for this purpose would be:

(a) Increase of transmitter power, especially by pulse methods.

(b) Use of the most sensitive receivers. Below the surface of the earth, much more sensitive receivers can be employed than above, as atmospheric disturbances are practically eliminated.

(c) Use of directional antennas.

One can calculate that by the use of all technically feasible means available today, ranges of several hundred kilometers would be possible in potash deposits. In the completely dry rock formations, below the deepest penetration of ground-water, still substantially larger ranges should be possible.

\subsection{Influence of Frequency}

Petrovsky [1908]; Ratcliffe, White [1930]; SmithRose [1933]; McPetrie [1934]; Sen-Gupta and Khastgir [1936]; Banerjee and Joshi [1938]; Khastgir and Charkravarty [1938]; Löb [1943]; Müller [1943]; Cooper [1948]. 
It was already pointed out in section 2.2 that attenuation is not given solely by eq (4). The dependence of attenuation on frequency is substantially more complicated and caused by additional effects, a great portion of which have not yet been sufficiently investigated. In general, one may observe an increase in attenuation with frequency. However, in the region between approximately 40 and $80 \mathrm{~m}$ wave length, the attenuation curve is a complicated function of frequency. Petrovsky and Fritsch [1960] have found in the course of their investigations that in several types of rock, e.g., in limestone of only low moisture content, attenuation can also decrease with increasing frequency. Its dependence on frequency is given by the "radiogeological curve." The distribution of water appears to have a substantial influence on this anomaly. Where the rocks do not contain water, as in potash deposits, no anomalies were observed. Ice layers always have high attenuation [Granier, 1924]. Finally, Wait $[1957,1959]$ explains the observed high values of the dielectric constant of the underground at low frequencies in terms of interfacial phenomena. The latter play an important role at audiofrequencies.

\subsection{Influence of the Geo-electrical Rock Structure}

Zuhrt [1933]; Fritsch [1936, 1937]; Wedensky [1937]; Fritsch [1944].

Substantial differences in conductivity and dielectric constant within most rock formations make it clear that the propagation of fields in these formations can also vary. The strong effect of absorbing clay and loam strata has already been mentioned. Also schist zones can show high attenuation rates which increase with the degree of mechanical breakdown. In figure 18 an iron mine is shown in plan view. Adjacent formations consist of dolomite, schist, and variegated sandstone. The dolomite shows resistivity values of several thousand ohmmeters. However, the extensively altered schist, which contains some water, has resistivity values below 100 ohmmeters. A transmitter, Jocated at point A, operating on a wavelength in the hundredmeter band, was received well as far as location $\mathrm{C}$ in tunnel 2, a range of $300 \mathrm{~m}$. In tunnel 1, reception was possible in the direction of B only as far as the limit of the schist at D, a distance of 30 to $40 \mathrm{~m}$. All tunnels were similarly equipped so that the same conditions for reception existed in all three directions.

Besides complete attenuation, the formation of shadows behind well-conducting zones was also observed. An example is shown by figure 19 . The field strength (expressed in relative units) decreases steeply within the region of the fissure containing mineral solutions whose resistivity amounts to approximately one-tenth of that of the other rock. However, the field strength increases again approximately $100 \mathrm{~m}$ beyond the fissure. Thus, a portion of the field may be completely absorbed within the region of the fissure, whereas another portion (the

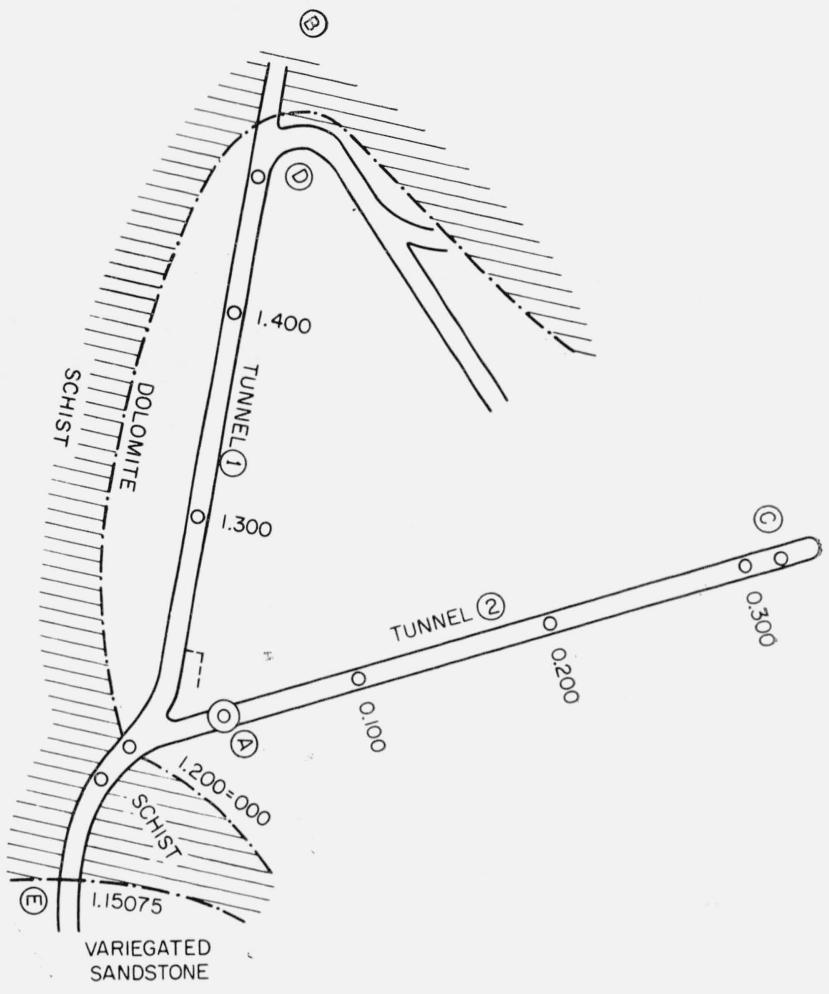

FIGURE 18. Influence of a schiit we lge

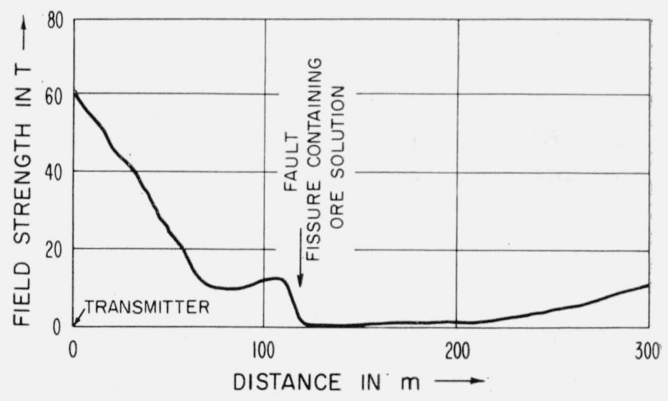

FIGURE 19. Shadowing behind a well-conducting fissure.

"circumventing wave," according to Petrovsky) is shunted around the fissure which is limited in spatial extent.

The test result shown in figure 20 demonstrates how large an effect small scale geologic structure may have on the propagation of radiofrequency electromagnetic fields. Figure 20 represents a horizontal cross section through a coal mine. The adjacent rocks are limestone. The obtained ranges are longest in the directions of the coal seams $(\mathrm{A}-\mathrm{B})$. In traversing a geologic discontinuity, (C-D) and $(\mathrm{E}-\mathrm{F})$, the range is sharply reduced. Also, when irradiating a very disturbed rock formation, $(\mathrm{C}-\mathrm{H})$, only a small range can be obtained. 


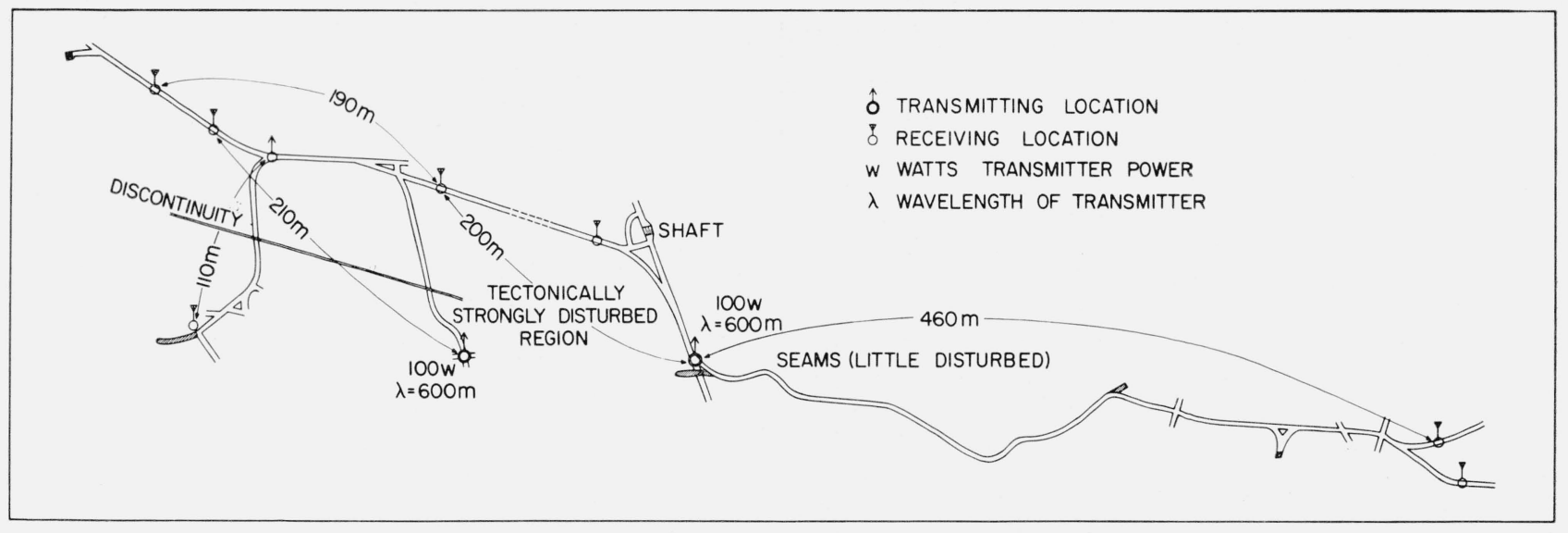

Figure 20. Propagation measurements in a coal mine.

Fields are also guided along well-defined geoelectrical planes of discontinuity. It is therefore possible for fields to be guided along different paths toward a measuring location, depending on the position of the geo-electrical discontinuities, and then to be combined with a deinite phase shift. This may then lead to effects within the rock formations which are similar to fading.

\section{Practical Significance of the Investiga- tions}

\subsection{Significance for Applied Geophysics}

Petrovsky, Skariatin, Selesnew, Dostavalov, and Kleinmann [1930]; Hartree [1931]; Bemalendu and Khastgir [1936]; Spieker [1937]; McKinnon [1940]; Horton [1946]; Pullen [1953]; Eliassen [1957].

First of all resistivity and dielectric constant of large volumes occupied by geological conductors can be determined by propagation measurements. The effect of frequency can be determined by field measurements much better than by laboratory measurements on small-size samples.

In the future, these procedures will certainly be used for the investigation of deep layers which have geo-electrical discontinuities. Below the deepest rocks containing water, the resisitivity of the rock formations are high enough, as already mentioned, to make substantial ranges possible. Thus, in this area there exists the theoretical possibility to prove the existence of deep discontinuities by measurement of reflection and refraction. In this respect, radiogeological procedures can supplement geo-electrical investigation methods, especially in those regions where direct current methods break down because of the low conductivity of the rock.

\subsection{Possibility of Subterranean Radio Communica- tion}

Dobbelstein [1912]; Ils]ey, Freeman, and Zellers [1928]; Fritsch [1946]; Felegy and Coggeshall [1948]; Bremmer [1949]; McGehee [1954].
In general, one certainly will not use radio communication below the surface of the earth. There are, however, exceptional cases where such methods are necessary. In mine catastrophes, all wire lines are often destroyed, leaving no way to talk with the trapped miners by telephone. In this case, it is often desirable to establish radio communication between central points and important locations within the mine, independent of wire lines. Also, such communication methods are necessary for military purposes with transmitters either located in underground cavities, or equipped with ground antennas [Doluchanov, 1956; Taylor, 1919], and others.

\section{Conclusions}

1. Ranges up to several kilometers are feasible below the surface of the earth.

2 . The obtainable ranges depend on attenuation in the geological conductors occupying the underground space, their geo-electrical structure, and the frequency of the field.

3 . The attenuation of a geological conductor is often a very complicated function of frequency. Many anomalies have been observed.

4. In the interior of rock formations, fields are guided along geo-electrical discontinuities. Effects similar to fading can be observed by superposition of fields guided along different paths.

5. It is now possible to measure the resistivity and the dielectric constant of large volumes occupied by geological conductors by the use of propagation tests. In the future, these measurements will also attain significance for tasks of applied geo-electricity. In many mines, it is possible to establish radio circuits which can be utilized in case of catastrophes.

\section{References}

Albert, J. L., V. V. Migulin, and P. A. Ryasin (1941), Investigation of the phase structure of the electromagnetic field and the velocity of radio waves, J. Phys. U.S.S.R. 4, No. $1 / 2,11-13$. 
Banerjee, S. S., and R. D. Joshi (1938), Dielectric constant and conductivity of soil at high radio frequencies, Phil. Mag. (7) 25, No. 172, 1025-1033.

Barrett, W. M. (1952), Note on the radio-transmission demonstrations at Grand Saline, Texas, Geophysics 1\%, $544-549$.

Bays, C. A. (1952), Study of the propagation of electromagnetic waves through lithologic formations, Quarterly Progress Report, Signal Corps Project No. 26-182B.

Beckmann, B. (1948), Die Ausbreitung der elektromagnetischen Wellen (Bücherei der HF-Technik, Akad. Verlag Ges. m.b.H., Leipzig).

Bimalendu, S. G., and S. R. Khastgir (1936), Direct determination of the electric constants of soil at radio frequency, Phil. Mag. (7) 22, No. 146, 265-273.

Bremmer, H. (1949), Terrestrial radio waves (Elsevier Publishing Co., Inc., New York).

Brüne, K. (1937), U̇ber die Ausbreitung elektromagnetischer Wellen in Wasser, Z. Hochfrequenztechnik 50, No. 3, $73-80$

Burgholz, R. (1944), Die im Untertagebetrieb von Steinkohlenzechen auftretrenden Funkstörungen, Telegraph.Fernspr.-Funk-u. Fernseh-Technik 33, No. 6, 120-126. Cooper, R. I. B. (1948), The attenuation of ultra-highfrequency electromagnetic radiation by rocks, Proc. Phys. Soc. 61, 40-47, 482-483.

Dobbelstein, O. (1912), Über drahtlose Grubentelephonie (Allgem. Bergmannstag, Wien, 122-132).

Doborzyński, D. (1936), UUber den Radioempfang in den Ojcow-Höhlen (in Polish), Przeglad Radjotechn., No. 7-8. Doborzyński, D. (1936), Experimenteller Beitrag zum Problem des unterirdischen Rundfunkempfanges, Hochfrequenztechn. u. E. 4\%, 12.

Doborzyński, D. (1937), Úber das Problem der RadioKommunikation in Bergwerken (in Polish) (PrzegladuGorniczo-Huntniczego).

Doluchanov, M. P. (1956), Die Ausbreitung von Funkwellen (VEB Verlag Technik, Berlin).

Eliassen, K. E. (1957), A survey of ground conductivity and dielectric constant in Norway within the frequency range $0.2-10 \mathrm{Mc} / \mathrm{s}$, Geofysiske Publ. Norske VidenskapsAkademi I, 19, No. 11, Oslo.

Eve, A. S. (1932), Absorption of electromagnetic induction and radiation by rocks, Trans. Am. Inst. Mining Met. Engrs. 97, 160-168.

Eve, A. S., D. A. Keys, and F. W. Lee (1929). Penetration of rocks by electromagnetic waves, Nature 124, No. 3118, $178-179$.

Felegy, E. W. (1953). Underground radio communication in Lake Superior District mines, Mining Eng. 5, 518-521.

Felegy, E. W., and E. J. Coggeshall (1948). Applicability of radio to emergency mine communications, U.S. Bureau of Mines Report R. J., No. 4294.

Fritsch, V. (1932). Beitrag zum Studium der Ausbreitung elektromagnetischer Felder in unterirdischen Hohlräumen, Hochfrequenztechn. u. E. 39, No. 4, 136-139.

Fritsch, V. (1933). Ausbreitung elektromagnetischer Felder längs Flussläufen, Hochfrequenztechn. u. E. 41, No. 3, $100-104$.

Fritsch, V. (1936). Dritte Mitteilung über die Bergradioversuche in Kotterbach, Hochfrequenztechn. u. E. 47, $190-195$.

Fritsch, V. (1937). Mitteilung über die Ergebnisse der in den Jahre 1930-1936 auf der Donau durchgeführten Funkversuche, Gerlands Beitr. Geophysik 51, No. 1, 1-28.

Fritsch, V. (1937). Beiträge zur Funkgeologie III. Einiges über die Ausbreitung Hertzscher Felder in Gebirgen, Beitr. angew. Geophysik 6, No. 3, 277-306.

Fritsch, V. (1939), Grundzüge der Funkgeologie (Verlag Friedr. Vieweg, Braunschweig).

Fritsch, V. (1939), Beitr. angew. Geophysik $\boldsymbol{\%}$, No. 4. See p. 452 .

Fritsch, V. (1942), Lo smorzamento delle onde Hertziane attraverso i conduttori geologici, Geofisica pura appl. 4, No. $1,15-37$

Fritsch, V. (1944), Beiträge zur Funkgeologie VIII. Ausbreitung Hertzscher Wellen in geologischen Leitern, Beitr. angew. Geophysik 11, No. 2, 163-199.

Fritsch, V. (1946), Die funkgeologischen Voraussetzungen für den Grubenfunk, Radiowelt 1, No. 3, 39-43; No. 4, 59-64.

Fritsch, V. (1948), Ausbreitung hochfrequenter Hertzscher Felder in Kalilagerstätten, Geofisica pura appl. 12, No. 1/2.

Fritsch, V. (1949), Grundzüge der angew. Geoelektrik (Wien). See Fig. 253.

Fritsch, V. (1952), Mitteilungen des Forschungsinstitutes Bad Gastein der Wiener Akademie der Wissenschaften, No. 74a.

Fritsch, V. (1960), Elektrische Messungen an räumlich ausgedehnten Leitern (Verlag G. Braun, Karlsruhe).

Fritsch, V. (1961), Messungen an räumlichen Leitern (Braunverlag, Karlsruhe).

Granier, J. (1924), Absorption des ondes électromagnétiques par la glace. Compt. Rend. hebd. Acad. Sci. 179, No. 23, $1313-1316$.

Grosskopf, J. (1942), Das Strahlungsbild eines vertikalen Dispolsenders über geschichtetem Boden, Hochfrequenztechn. u. E. 60, 136-141.

Grosskopf, J. (1943). Die Ausbreitung elektromagnetischer Wellen über inhomogenem Boden, Hochfrequenztechn. u. E. 62, 103.

Grosskopf, J., and K. Vogt (1940), T. F. T. 29, 164. See Fig. 2.

Grosskopf, J., and K. Vogt (1941), Hochfrequenzt. u. E. 58, 55. See Fig. 6.

Grosskopf, J., and K. Vogt (1943), Der Zusammenhang zwischen der effektiven Bodenleitfähigkeit und der Ausbreitungsdämpfung, Hochfrequenztechn. u. E. 62, 14.

Hack, F. (1908), Die Ausbreitung ebener elektromagnetischer Wellen längs eines geschichteten Leiters, besonders in den Fällen der drahtlosen Telegraphie, Hochfrequenztechn. u. E. $\mathbf{2 ,} 165$.

Hartee, D. R. (1931), Optic and equivalent paths in a stratified medium, treated from a wave standpoint, Proc. Roy. Soc. (A), 131, 428-450.

Hayeock, O. C., E. C. Madsen, and S. R. Hurst (1949), Propagation of electromagnetic waves in the earth, Geophysics 14, 162-171.

Horton, C. W. (1946). On the use of electromagnetic waves in geophysical prospecting, Geophysics 11, 505 .

Howell, B. F. (1943). Some effects of geologic structure on radio reception, Geophysics $\mathbf{8 ,} 165-176$.

Hummel, J. N. (1935), Unterlagen der geoelektrischen Aufschliessungsmethoden, Beitr. Ang. Geophys. 5, 32.

Ilsley, L. C., H. B. Freeman, and D. H. Zellers (1928), Experiment in underground communication through earth strata, Dept. of Commerce, Bur. of Mines, Tech. Paper 433.

Joyce, J. W. (1931), Electromagnetic absorption by rocks with some experimental observations taken at Mammoth Cave in Kentucky, Bur. of Mines, Tech. Paper 497.

Jung, H. (1950), Bedeutung der Hochfrequenz für den Bergbau, Elektrotechnik 4, 145-149.

Kerr, D. E. (1951), Propagation of short radio waves (McGraw-Hill Book Co. Inc., New York). See especially p. 396.

Khastgir, S. R., and M. K. Charkravarty (1938), Direct determination of the electr. constants of soil at ultra high radio frequencies, Phil. Mag. (7), 25, 793.

Krajew, A. P. (1957), Grundlagen der Geoelektrik (VEB Verlag Technik, Berlin).

Kühn, U. (1958), Ausbreitungsuntersuchungen über unterschiedlichem Gelände, Techn. Mittlgn. BRF, No. 2, 41-43.

Lichtenecker, K. (1924), Der elektrische Leitungswiderstand künstlicher und natürlicher Aggregate, Phys. Z. 25, 169, $193,225$.

Löb, E. (1943), Die Dielektrizitätskonstante und der Verlustwinkel von trockenem und feuchtem Sand bei Zentimeterwellen, Hochfrequenztechn. u. E. 61, No. 2, 35-38.

Lorenz, L., and H. A. Lorentz (1880), Wied. Ann. 9, 641.

Löwy, H. (1920), Elektrodynamische Erforschung des Erdinnern und Luftschiffahrt (Manz'sche Verlagshandlg., Wien).

Löwy, H. (1940), Dielektrizitätskonstante und Leitfähigkeit der Gesteine, Ann. Physik (4) 36, 125.

McGehee, Jr. F. M. (1954), Propagation of radio frequency energy through the earth, Geophysics 19, No. 3, 459-477.

McKinnon, K. A. (1940), Radiofrequency measurements of ground conductivity in Canada, Can. J. Res. (A), 18, 123.

McPetrie (1934), A determination of the electrical constants 
of the earth's surface at wavelengths of 1.5 and $0.46 \mathrm{~m}$, Proc. Phys. Soc. 46, No. 5, 637-648.

Millington, G., and G. A. Isted (1950), Ground-wave propagation over an inhomogenous smooth earth, Proc. Inst. Elect. Engrs., Part III, 209-222.

Müller, M. (1943), Die Messung der Frequenzabhängigkeit der elektrischen Leitfähigkeit und Dielektrizitätskonstante von Gesteinsproben, Z. Geophysik 18, 59-66.

Niessen, K. F. (1938), Zur Entscheidung zwischen horizontalen oder vertikalen elektr. Dipolen zwecks minimaler Erdabsorption bei gegebener Bodenart und Wellenlänge, Ann. Physik V 33, 404-418.

Petrovsky, A. (1908), Über die Ausbreitung der Wellen eines Hertzschen Oscillators, der in einem leitenden Mittel steht, Bull. Peterburger Akad. Wiss. 1217. In Russian.

Petrovsky, A. (1929). Úber die unmittelbare Messung der Länge der elektromagnetischen Wellen und uber die Anisotropie derselben im Berggestein, Vestnik Elektrotechniki 1, No. 11/12, 329-339. In Russian.

Petrovsky, A. (1933), Über die Anwendung der elektromagnetischen Wellen zur Bodenforschung in der USSR, Beitr. ang. Geophysik 3, 149-204.

Petrovsky, A. (1947), Der erste Versuch über die Fortpflanzung Hertzscher Wellen durch ewig gefrorenen Boden, Trudy Inst. Merzlotovendenija imeni, V.A. Obrucheva 5, In Russian.

Petrovsky, A., R. Skariatin, A. Selesnew, B. N. Dostavalov, and L. Kleinmann (1930), Úber die ondometrischen Arbeiten des Institutes für die angewandte Geophysik, Arbeiten des J.A.G. 45-69. In Russian.

Polic, B. (1944), Die Untersuchung der Ausbreitung von elektromagnetischen Wellen in Gebirgs-, Flusstälern, Fjorden usw. mittels Modellen, T.F.T. 33, 63.

Pritchett, W. C. (1952), Attenuation of radio frequency waves through the earth, Geophysics 17, No. 2, 193-217.

Pullen, M. W. (1953), Geologic aspects of radio wave transmission, State Geol. Surv. Rep. of Invest. Urbana, Ill., No. 162,73

Ratcliffe, J. A., and F. W. G. White (1930), The electrical properties of the soil at radio frequencies, Phil. Mag. (7), 10, No. 65, 667-680

Schumann, W. O. (1948), Elektrische Wellen. (C. HauserVerlag, München). See especially p. 51.

Sen-Gupta, B., and S. R. Khastgir (1936), Direct determination of the electric constants of soil at radio frequency, Phil. Mag. (7), 22, No. 146, 265-273.

Silverman, D., and D. Sheffet (1942), Note on the transmission of radio waves through the earth, Geophysics $\boldsymbol{y}$, $406-413$.

Smith-Rose, R. L. (1933), The electrical properties of soil for alternating currents at radio frequencies, Proc. Roy. Soc. London (A), 140, 359 .

Smith-Rose, R. L. (1935), The electrical properties of soil at frequencies up to 100 megacycles per second, Proc. Phys. Soc. 47, 923.

Smith-Rose, R. L., and R. H. Barfield (1926), The attenuation of wireless waves due to the resistance of the earth, J. Inst. Elect. Eng. 64, No. 355, 766.

Smith-Rose, R. L. (1957), Advances in electronics and electron physics, Physics 9, 187-238.

Sommerfeld, A. (1910), Ausbreitung der Wellen in der drahtlosen Telegraphie. Einfluss der Bodenbeschaffenheit auf gerichtete und ungerichtete Wellenzüge, Jahrb. drahtl. Telegr, u. Telephonie 4, 157-176.
Spieker, E. M. (1937), Radio-transmission and geology, Bull. Am. Assoc. Petrol. Geol. 20, 1123.

Stern, W. (1931), Über die Ausbreitung elektromagnetischer Wellen hoher Frequenz im bergfeuchten Gebirge, Beitr. z. angew. Geophysik 1, 437.

Stipanits, M. (1938), Die drahtlose Verständigung im Bergbau und die Funkversuche im Dreifaltigkeitsschacht in Schlesisch-Ostrau, Montanist. Rundschau 30, No. 28, 1-5.

Strutt, M. J. O. (1932), Der Einfluss der Erdbodeneigenschaften auf die Ausbreitung elektromagnetischer Wellen, Hochfrequenztechn. u. E. 39, No. 5, 177-185.

Tarchov, A. G. (1955), Radiovolnovoj metod elektro razvedki, Tr. Mosk. Geol.-Razvedoch. Inst. 28, 215.

Taylor, A. H. (1919), Short-wave reception and transmission on ground wires (Subterranean and Submarine), Proc. IRE \%, 337.

Träumer, F., and M. Müller (1957), Die Ausbreitung der Bodenwellen über inhomogenen Untergrund, Tech. Mitt. Beitr. Lab. Rundfunk u. Fernsehen No. 2, 21.

Wadley, T. L. (1946), Underground communication by radio in gold mines on the Witwaterstrand, Report T.R.L., No. 3.

Wait, J. R. (1953), Radiation from a vertical dipole over a stratified ground, IRE Trans. Ant. Prop. AP-1, No. $1,9-12$.

Wait, J. R. (1954), Theory of electromagnetic surface waves over geological conductors, Geofis. Pura Appl. 28, 47-56.

Wait, J. R. (1957), The effective electrical constants of soil at low frequencies, Proc. IRE 45, No. 10.

Wait, J. R. (1959), Overvoltage research in geophysical applications (Pergamon Press, New York, and London).

Wäller, W. (1954), Sprechverbindungen in Bergwerken unter Tage, Elektrotech. Z. (A), 75, No. 5, 191-194.

Wedensky, B. (1937), Formeln für Ausbreitung und Beugung von Hochfrequenzwellen unter Berücksichtigung der Dielektrizitätskonstanten der Erde, Tech. Phys. USSR 4, No. 8, 579. In Russian.

Wiener, O. (1912), Die Theorie des Mischkörpers für das Feld der stationären Strömung, Abhandl. Leipziger Akad. 32, 519.

Wise, Howard W. (1930), Note on the accuracy of Rolf's graphs of Sommerfeld's attenuation formula, Proc. IRE 18, 1971

Wolf, A. (1946), Electric field of an oscillating dipole on the surface of a two-layer earth, Geophysics 11, 518-537.

Wundt, R. M. (1940). Ein Beitrag zur Brechung elektrischer Wellen an der Erdoberfläche, Verhandl. deut. physik Ges. 21, No. 2, 43.

Zehnder, L. (1911). Beruht die drahtlose Telegraphie auf die Ausbreitung Hertzscher Wellen in der Erde? Elektrotech. Z., 1101.

Zenneck, J. (1907), U̇ber die Fortpflanzung ebener elektromagnetischer Wellen längs einer ebenen Leiterfläche und ihre Beziehung zur drahtlosen Telegraphie, Ann. Physik (4) 23, 846-866.

Zuhrt, H. (1938), Über die Dämpfung von Kurzwellen durch leitende Wände, Hochfrequenztechn. u. E. 41, 205-207.

Zuhrt, H. (1953), Elektromagnetische Strahlungsfelder (Springer-Verlag, Berlin), See especially p. 445. 